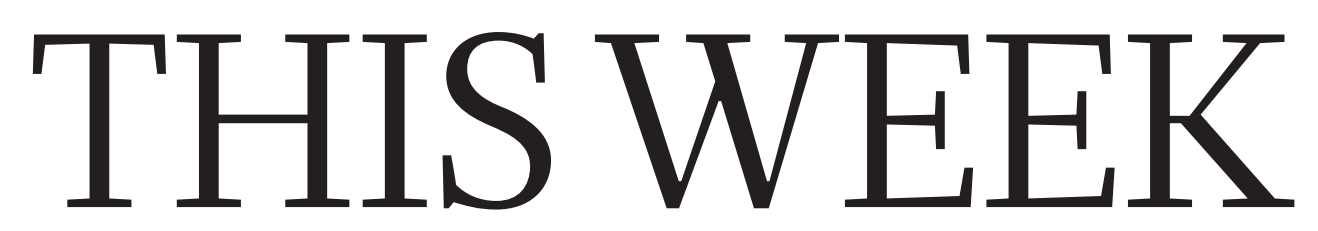

NEUROSCIENCE Searching for the seat of pain in the brain $\mathbf{p . 4 5 6}$
WORLD VIEW Islamic scholars must focus on political groups $\mathbf{p . 4 5 7}$
ORGANS Gel with cells and nutrients could print tissues $\mathbf{p . 4 5 8}$

\title{
When right beats might
}

\section{The final act in a long-running Italian saga should bring tighter controls on unproven stem-cell therapies, both at home and abroad.}

W hat impact can scientists have on the murky world of politics? When the Italian stem-cell researcher Elena Cattaneo was appointed senator in her nation's parliament in 2013, she carried the hopes of her colleagues that she could make a difference. Italian courts and politicians were authorizing unproven and potentially dangerous stem-cell therapies. The emotions of vulnerable and desperately ill people were being played with for commercial gain. Reporters, including those from this journal, who tried to expose the shameful situation were lied to, obstructed and threatened with legal action. Signora Cattaneo went to Rome. Together with other stem-cell researchers, she helped to bring an end to the whole sorry affair. Brava!

In her research at the University of Milan, Cattaneo investigates the conversion of embryonic stem cells into mature nerve cells, and how this might one day be used to treat neurological diseases. Across the world, the development of such treatments, and how they should be tested, introduced and regulated, is pitting careful, evidence-based approaches against medical opportunists. Until recently, Italy was an example of how to get it wrong. Now it has an opportunity to show how it - and the rest of the world - can get it right.

For seven years, the Stamina Foundation sold unproven stem-cell therapies to Italian people as a panacea for any number of conditions. A report into the affair published by the Italian Senate last week analyses what went wrong. It details the complicated history of the affair, and identifies the sorry list of characters - including many politicians who must share the blame.

The report makes ten sensible proposals to fix the system. Politicians must now fine-tune and enact them. Stamina's is not the only unproven therapy to be indulged by the Italian state in recent times, but it needs to be the last. Scientists and policy-makers in other countries would be wise to take the lessons on board, too, because such lessons show that being right is not enough to stop harm from being done.

Most strikingly, the Senate investigation found no systematic failure in the state's technical agencies mandated to protect the public. The message from scientific experts in these agencies was loud and clear: that the Stamina claims had no merit and the technique carried considerable risks. But this expertise was ignored by other pillars of the state: the legislature and judiciary.

In 2012, the Italian Medicines Agency had declared the Stamina treatment unsafe, and ordered the closure of the company's laboratory in a Brescia hospital. But, egged on by Stamina's relentless campaigning, more than 450 people took to local courts and demanded the therapy anyway, on compassionate grounds. About half of them got it. Politicians, fearing an electoral backlash if they seemed to be ignoring patients, followed - even though they knew that a police investigation was under way.

The politicians went further. Despite formal advice from their own scientific agencies, they approved ministerial decrees to promote the Stamina treatment, including one that set up a state-sponsored clinical trial.

Scientists around the world looked on incredulously as the treatments continued until August 2014, when a Turin court finally ordered the confiscation of equipment and cells from the Stamina laboratory.

A small group of scientists from across Italy, including Cattaneo, fought relentlessly and at great personal cost against the politically powerful Stamina supporters. Their story is told in a 2014 Nature Comment (E. Cattaneo and G. Corbellini Nature 510, 333-335; 2014). When Cattaneo was appointed to the Senate by former Italian president Giorgio Napolitano, this fight acquired another dimension. Her first action was to push for the Senate investigation. The 15-strong commission began work at the end of January last year, sifting through documents and holding 25 hearings to assess evidence that anti-Stamina campaigners would have been unable to find.

One of the report's proposals is that any future court that is asked to recommend an unauthorized treatment on compassionate grounds should have a representative of the health ministry and the state prose-

"The Stamina case has been a disgrace to Italy, but it shows the influence that individual scientists can have infighting antiscience forces." passionate use of unauthorized therapies, to
close loopholes that could lead to abuse. It suggests new rules to ensure that ethics committees are truly independent, and recommends guidelines for media reporting similar to those adopted by the BBC last year.

Italian scientists are often disheartened by the lack of respect for science in their country. They are still reeling from the manslaughter verdict meted out by a court to seismologists who had advised the government before the major 2009 earthquake in L'Aquila; the convictions were overturned on appeal last year. Moreover, the Stamina case has a close parallel in the notorious case of Luigi Di Bella, a physician who claimed in the 1990s that a mixture of molecules such as somatostatin, together with vitamins, could cure cancer.

The Stamina case has been a disgrace to Italy, but it shows the influence that individual scientists can have in fighting - even against seemingly impossible odds - anti-science forces. And as if to underline the point that science can prevail in the most hostile of environments, a day after publication of the Senate report, the European Commission formally authorized the Western world's first-ever approval for a stem-cell therapy: a treatment for a rare type of blindness that has been developed entirely by Italian scientists, working exclusively in Italy.

It is not just in the political world that researchers can help others to see more clearly.. 